\title{
Upregulation of heme oxygenase-1 expression by curcumin conferring protection from hydrogen peroxide-induced apoptosis in $\mathrm{H} 9 \mathrm{c} 2$ cardiomyoblasts
}

\author{
Xiaobo Yang ${ }^{1}$, Hong Jiang ${ }^{2}$ and Yao Shi $2^{*}$
}

\begin{abstract}
Background: Curcumin is a major constituent of rhizomes of Curcuma longa that elicits beneficial effects for oxidative damage. The aim of this study was to investigate whether curcumin could attenuate hydrogen peroxide $\left(\mathrm{H}_{2} \mathrm{O}_{2}\right)$-induced apoptosis in $\mathrm{H9c} 2$ cardiomyoblasts and the underlying mechanisms.

Results: The present study showed that exposure of $\mathrm{H} 9 \mathrm{c} 2$ cells to $\mathrm{H}_{2} \mathrm{O}_{2}$ caused a significant increase in apoptosis as evaluated by flow cytometry analysis and the pretreatment of curcumin protected against $\mathrm{H}_{2} \mathrm{O}_{2}$-induced apoptosis. Exposure of cells with curcumin caused a dose-dependent induction of heme oxygenase-1 (HO-1) protein expression. Curcumin also decreased the cleaved caspase-3 (CC3) protein expression level and increased the $\mathrm{BCl}-2 / \mathrm{Bax}$ ratio in $\mathrm{H}_{2} \mathrm{O}_{2}$-stimulated $\mathrm{H} 9 \mathrm{c} 2$ cells. ZnPP-IX, a HO-1 inhibitor, partly reversed the anti-apoptotic effect of curcumin. Further, LY294002, an inhibitor of PI3K, partially reversed the effect of curcumin on HO-1 protein induction, leading to the attenuation of curcumin-mediated apoptosis resistance.

Conclusion: These results demonstrated that the anti-apoptotic function of curcumin required the upregulation of HO-1 protein through the PI3K/Akt signaling pathway. Curcumin might be used as a preventive and therapeutic agent for treatment of cardiovascular diseases associated with oxidative stress.
\end{abstract}

Keywords: Curcumin, Cardiomyocyte apoptosis, Oxidative stress, Heme oxygenase-1, PI3K/Akt

\section{Background}

Oxidative stress-induced apoptosis has long been implicated in the pathogenesis of cardiovascular diseases such as myocardial ischemic injury and infarction $[1,2]$. Oxidative damage, mediated by reactive oxygen species (ROS) which can be generated following cell lysis, oxidative burst, or the presence of an excess of free transition metals, can attack proteins, DNA, and membrane lipids, thereby leading to the loss of cell integrity, enzyme function, and genomic stability $[3,4]$. Therefore, therapeutic

\footnotetext{
*Correspondence: y_l_h726@sina.com

${ }^{2}$ Department of Neonatology, The Central Hospital of Wuhan, Tongji Medical College, Huazhong University of Science and Technology, Wuhan, 430014, China

Full list of author information is available at the end of the article
}

intervention targeting the apoptosis is a reasonable strategy for the treatment of cardiovascular diseases.

Curcumin, a major component of turmeric powder extracted from the rhizomes of the plant Curcuma longa, has been applied for centuries in indigenous medicine to treat various diseases [5]. This bioactive phytochemical is a potent inhibitor of tumor promotion and possesses antiinflammatory and anti-oxidative activities [6]. In addition, curcumin seems to be, even at relatively low concentrations, an effective anti-apoptotic agent [7]. One study reported that curcumin attenuated peroxynitrite-induced apoptosis in primary cultured rat spiral ganglion neurons [8], and another study demonstrated that curcumin had the potential to protect experimental autoimmune myocarditis [9]. Nevertheless, the possible protective effect of curcumin on the toxicity in cardiomyoblasts has not 
been tested in vitro. Furthermore, the precise mechanism underlying this response is still unclear.

Heme oxygenase-1 (HO-1), which is the rate-limiting enzyme responsible for the degradation of heme into free ferrous iron, carbon monoxide (CO) and bilirubin, exerts cytoprotective effects in various diseases [10,11]. Recent experimental evidence indicated that increased $\mathrm{HO}-1$ production provided cellular protection against oxidative injury induced by ischemia/reperfusion [12] or the use of hydrogen peroxide $\left(\mathrm{H}_{2} \mathrm{O}_{2}\right)[13,14]$. Protein kinase $\mathrm{B}$ (PKB, Akt), one of the most important downstream target kinases of phosphoinositide 3-kinase (PI3K), is an important signaling molecule activated by anti-apoptotic agents [15], while extracellular signal-regulated kinases (ERKs) mediate another important signaling pathway involved in anti-apoptotic effects [16]. Several studies reported that HO-1 provided protection against various forms of stress through the activation of the PI3K/Akt or ERK1/2 signaling pathways $[17,18]$.

The H9c2 cell line, derived from the embryonic BDIX rat heart ventricle, is considered a close surrogate for cardiomyocytes and has been proven to be ideal for signal transduction studies [19]. $\mathrm{H}_{2} \mathrm{O}_{2}$, as one of the main ROS, could cause DNA damage and lipid peroxidation and has been widely used to induce apoptosis in various cell types [20]. In this study, $\mathrm{H}_{2} \mathrm{O}_{2}$ was used to induce apoptosis in H9c2 cells, as it is a well-established model to study oxidative stress-induced cardiomyocyte apoptosis [21, 22]. Here we aimed to investigate the anti-apoptotic effect of curcumin in $\mathrm{H}_{2} \mathrm{O}_{2}$-stimulated $\mathrm{H} 9 \mathrm{c} 2$ cells and to explore the role of $\mathrm{HO}-1$ and its associated signaling pathways.

\section{Methods}

\section{Chemicals and reagents}

Curcumin, Zine protoporphyrin-IX (ZnPP-IX, a HO-1 inhibitor), dimethyl sulfoxide (DMSO), $\mathrm{H}_{2} \mathrm{O}_{2}$ and methyl thiazolyl tetrazolium (MTT) were from Sigma Chemical. LY294002 (a PI3K inhibitor) and rabbit polyclonal antibodies specific for total ERK1/2 (t-ERK1/2), phospho-ERK1/2 (p-ERK1/2), total Akt (t-Akt), phospho-Akt (p-Akt, serine 473), Bcl-2, Bax, cleaved caspase-3 (CC3) and GAPDH were from cell signaling. Rabbit polyclonal antibodies specific for HO-1 were obtained from Stressgen Bioreagents.

\section{Cell culture}

H9c2 cardiomyoblasts from the American Type Culture Collection (ATCC, CRL-1446) were maintained in DMEM supplemented with $10 \%$ heat-inactivated fetal bovine serum, $100 \mathrm{U} / \mathrm{mL}$ penicillin and $100 \mu \mathrm{g} / \mathrm{mL}$ streptomycin in a humid atmosphere of $5 \% \mathrm{CO}_{2}$ and $95 \%$ air at $37^{\circ} \mathrm{C}$. Cells were regularly passaged and subcultured to $90 \%$ confluence before experimental procedures.
Curcumin dissolved in DMSO was diluted with lowserum medium (1\% FBS/DMEM) to the final concentrations before use. The final concentration of DMSO in the incubation mixture was not more than $0.1 \%(\mathrm{v} / \mathrm{v})$.

\section{Cell viability assay}

Cell viability was assessed by MTT assay. Briefly, the H9c2 cells subcultured in 96-well plates at $1 \times 10^{4}$ cells/ well were incubated with the test chemicals for indicated time period. Then $5 \mathrm{mg} / \mathrm{mL}$ MTT was added to the culture media and cells were incubated further for an additional $4 \mathrm{~h}$. After this incubation, the formed formazan was solubilized by adding DMSO, and optical density of the solubilized cell extract was measured at $490 \mathrm{~nm}$ using a microplate reader. The reduction in optical density was considered being the decrease in cell viability.

\section{Annexin-V FITC/PI assay}

Apoptosis was detected using an Annexin-V FITC/PI detection kit according to the manufacturer's directions (KeyGEN, Nanjing, China). The cells were digested with $0.25 \%$ trypsin, washed with ice-cold PBS and resuspended in binding buffer $\left(5 \times 10^{5}\right.$ cells $\left./ \mathrm{mL}\right)$. Then, the cells were centrifuged at $1000 \mathrm{~g}$ for $5 \mathrm{~min}$ at $4{ }^{\circ} \mathrm{C}$. After the supernatant had been discarded, $500 \mu \mathrm{L}$ of binding buffer, $5 \mu \mathrm{L}$ of annexin-V-FITC and $5 \mu \mathrm{L}$ of propidium iodide were added to the cell suspension. After mixing gently, the suspensions were incubated for $15 \mathrm{~min}$ at room temperature without light. Finally, the cells were analyzed by flow cytometry (BD LSRII; BD Biosciences).

\section{Western blot analysis}

Cells were lysed in ice-cold cell lysis buffer. The protein concentration was determined using BCA method. Protein was separated by SDS-PAGE, and then transferred onto polyvinylidene difluoride membrane. The membranes were blocked in TBS-T with $5 \%(\mathrm{w} / \mathrm{v})$ skim milk at room temperature for $2 \mathrm{~h}$, followed by overnight incubation at $4{ }^{\circ} \mathrm{C}$ with primary antibodies diluted in TBS-T. After washing in TBS-T, the membranes were incubated for $1 \mathrm{~h}$ with a horseradish peroxidase-conjugated secondary antibody diluted in TBS-T. After washing once more in TBS-T, the labeled protein was detected using enhanced chemiluminescence reagents and exposed to film. The intensity of the bands was analyzed with Alpha Ease FC image software.

\section{Statistical analysis}

All data represented the mean of samples from three independent experiments. Results were presented as mean and standard deviation (mean \pm SD). Statistical significance was determined by one-way ANOVA followed by Student-Newman-Keuls test for comparison of 
several groups. A $p$ value less than 0.05 was considered being statistically significant.

\section{Results}

Curcumin reduced $\mathrm{H}_{2} \mathrm{O}_{2}$-induced cell toxicity

As shown in Fig. 1a, 200-600 $\mu \mathrm{M} \mathrm{H}_{2} \mathrm{O}_{2}$ reduced the cell viability in a dose-dependent manner. In the presence of 400 and $600 \mu \mathrm{M}$ of $\mathrm{H}_{2} \mathrm{O}_{2}$, the percentage of viable cells was reduced to $58.92 \pm 8.02$ and $37.76 \pm 8.54 \%$ of the control, respectively $(p<0.05)$. Then we evaluated whether curcumin was cytotoxic to H9c2 cells. As shown in Fig. 1b, cell viability was not significantly affected by treatment with increasing doses of curcumin up to $15 \mu \mathrm{M}$ compared to that of the control group. However, a significant decrease in cell viability was observed in cells treated with 20 and $25 \mu \mathrm{M}$ curcumin $(87.88 \pm 9.85$ and $65.3 \pm 10.94 \%$ of the control, $p<0.05)$. Next, we tested whether the pretreatment with curcumin was able to protect against $\mathrm{H}_{2} \mathrm{O}_{2}$-induced cytotoxicity. As shown in Fig. 1c, pretreatment with 10 and $15 \mu \mathrm{M}$ of curcumin significantly increased the cell viability to $73.61 \pm 8.14$ and $84.93 \pm 8.41 \%$ of the control, respectively. Our results indicate that curcumin may have protective role against $\mathrm{H}_{2} \mathrm{O}_{2}$-induced cell death.

\section{Curcumin increased $\mathrm{HO}-1$ protein expression}

Curcumin treatment for $12 \mathrm{~h}$ increased HO-1 protein expression in a dose-dependent manner (Fig. 2a). Curcumin $(15 \mu \mathrm{M})$ induced a significant increase of HO-1 protein expression for the 3-time points tested, with a maximum of $3.06 \pm 0.31$-fold increase after the $12 \mathrm{~h}$ treatment (Fig. 2b).

\section{The anti-apoptotic effect of curcumin was reversed} by ZnPP-IX

As shown in Fig. 3a, b, $400 \mu \mathrm{M}$ of $\mathrm{H}_{2} \mathrm{O}_{2}$ led to a significant increase in apoptosis in $\mathrm{H} 9 \mathrm{c} 2$ cells compared with the control group, and apoptosis was decreased markedly by curcumin. The anti-apoptotic effect of curcumin was notably reversed by ZnPP-IX. We next showed that H9c2 cells subjected to $\mathrm{H}_{2} \mathrm{O}_{2}$ had decreased $\mathrm{Bcl}-2 / \mathrm{Bax}$ ratio compared with the control group, while curcumin pretreatment increased the $\mathrm{Bcl}-2 / \mathrm{Bax}$ ratio compared with the $\mathrm{H}_{2} \mathrm{O}_{2}$ group. Again, this effect of curcumin was partly blocked by ZnPP-IX (Fig. 3c). Furthermore, western blot analysis also showed that $\mathrm{H}_{2} \mathrm{O}_{2}$ caused a significant increase in CC3 levels compared with the control which is reduced by the pretreatment with curcumin. Co-incubation with ZnPP-IX partly negated this effect of curcumin (Fig. 3d).

\section{Curcumin enhanced phosphorylation of Akt but had no influence on ERK $1 / 2$ phosphorylation}

As shown in Fig. 4, the levels of p-Akt increased remarkably in the first $30 \mathrm{~min}$ and then began to decrease continuously in the following hours, while curcumin had no significant influence on p-ERK $1 / 2$ at any time point tested. In addition, total levels of Akt and ERK1/2 did not change significantly among these treatments.

\section{Influence of LY294002 on apoptosis and HO-1 expression}

To determine whether the activation of the PI3K/Akt pathway by curcumin is instrumental to the survival of H9c2 cells by modulating HO-1 expression, we tested the effects of LY294002 (an inhibitor of PI3K) on the protein expression of CC3 and HO-1. As shown in Fig. 5a, curcumin decreased the CC-3 protein expression levels compared with the $\mathrm{H}_{2} \mathrm{O}_{2}$ group, but this effect was largely negated by LY294002. The increase of HO-1 protein expression induced by curcumin was also partly abolished by LY294002. Furthermore, curcumin increased the $\mathrm{Bcl}-2 / \mathrm{Bax}$ ratio compared with the $\mathrm{H}_{2} \mathrm{O}_{2}$ group. And this effect of curcumin was also partially blocked by LY294002 (Fig. 5b). As expected, Akt phosphorylation enhanced by curcumin was completely reduced by
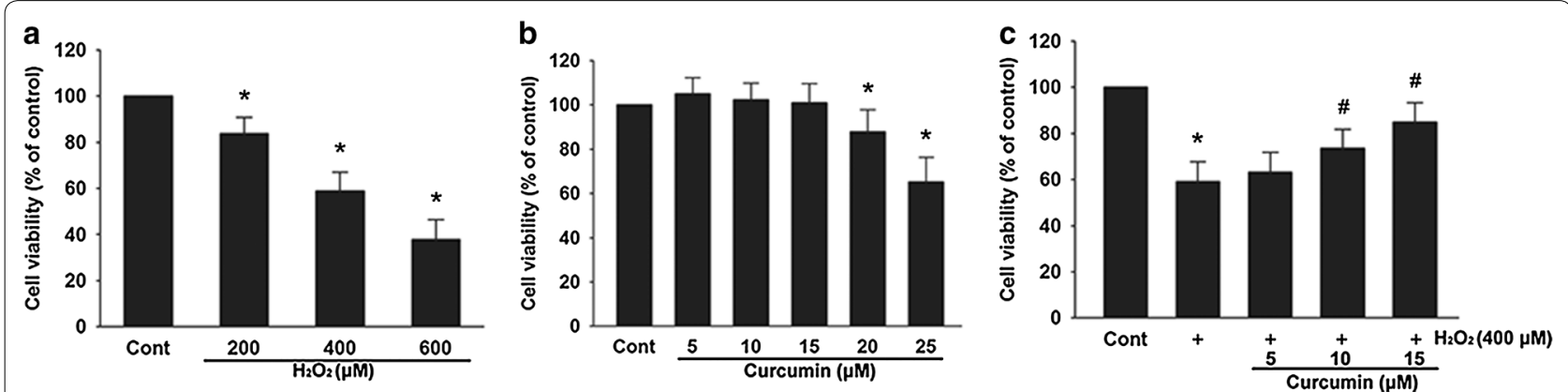

Fig. 1 Curcumin reduced $\mathrm{H}_{2} \mathrm{O}_{2}$-induced cell toxicity. Cell viability was examined using the MTT assay. a Effect of $\mathrm{H}_{2} \mathrm{O}_{2}$ on cell viability. Cells were treated with $200-600 \mu \mathrm{M}$ of $\mathrm{H}_{2} \mathrm{O}_{2}$ for $3 \mathrm{~h}$. b Effect of curcumin on cell viability. Cells were treated with $5-25 \mu \mathrm{M}$ of curcumin for $24 \mathrm{~h}$. c Curcumin protected the cells from $\mathrm{H}_{2} \mathrm{O}_{2}$-induced cytotoxicity in a dose-dependent manner. After pretreated with 5-15 $\mu \mathrm{M}$ of curcumin for $12 \mathrm{~h}$, the cells were washed and incubated with $400 \mu \mathrm{M} \mathrm{H}_{2} \mathrm{O}_{2}$ for $3 \mathrm{~h}$. Data were presented as mean $\pm \mathrm{SD}(\mathrm{n}=3)$. ${ }^{*} p<0.05$ vs. Cont (control), ${ }^{*} p<0.05$ vs. $\mathrm{H}_{2} \mathrm{O}_{2}$ 

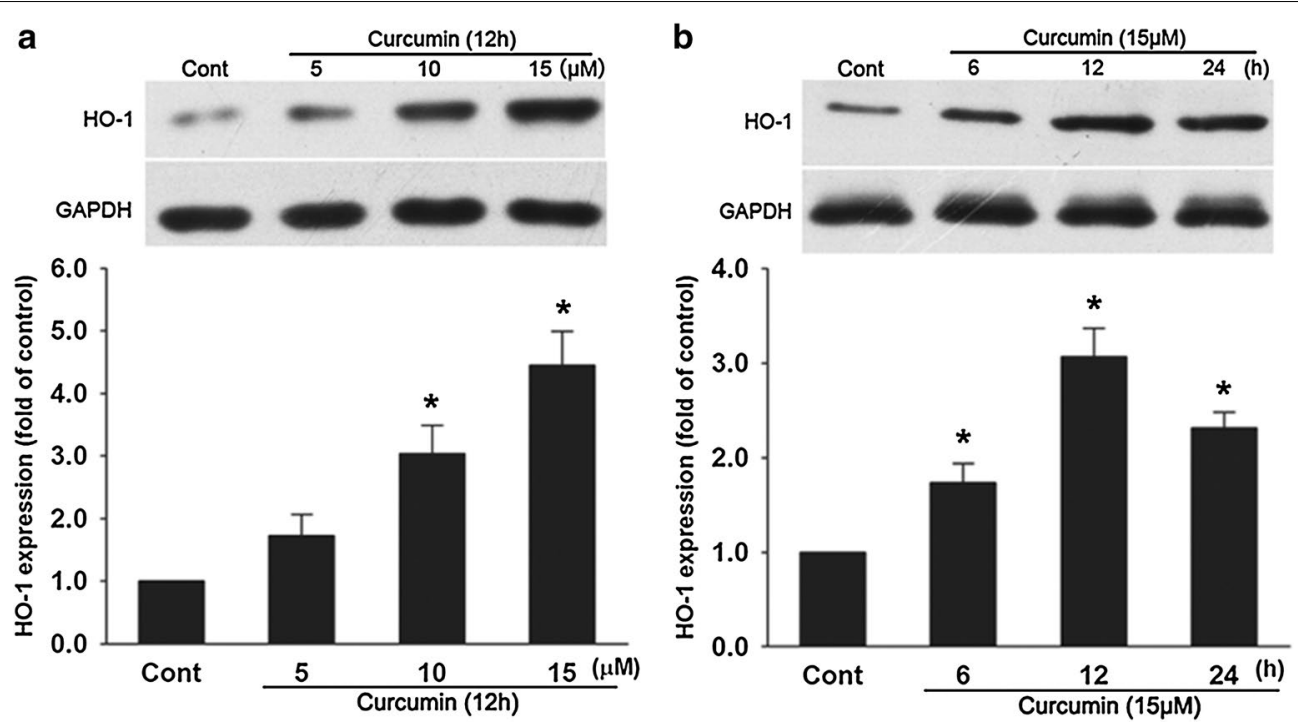

Fig. 2 Curcumin increased HO-1 protein expression. a Cells were incubated with 5-15 $\mu \mathrm{M}$ of curcumin for $12 \mathrm{~h}$ as indicated. b Cells were incubated with $15 \mu \mathrm{M}$ of curcumin for the indicated amounts of time. HO-1 protein expression was determined by western blot analysis. Data were presented as mean $\pm \mathrm{SD}(\mathrm{n}=3) .{ }^{*} p<0.05$ vs. Cont

LY294002 (Fig. 5c). Co-incubation with LY294002 partly negated the increase of $\mathrm{HO}-1$ induced by curcumin (Fig. 5d).

\section{Discussion}

$\mathrm{H}_{2} \mathrm{O}_{2}$ is a strong oxidant that can cause a marked decrease in cell viability. The present study confirmed that treating $\mathrm{H} 9 \mathrm{c} 2$ cells with $\mathrm{H}_{2} \mathrm{O}_{2}$ resulted in a dosedependent viability loss. Curcumin is a hormetic compound, at higher doses it is cytotoxic, but at lower doses, it is implicated in cellular adaptive stress responses [23]. Our study showed that administration of curcumin at higher doses $(20$ and $25 \mu \mathrm{M})$ for $24 \mathrm{~h}$ induced cell death, whereas curcumin lower than $15 \mu \mathrm{M}$ (including $15 \mu \mathrm{M}$ ) were nontoxic to $\mathrm{H} 9 \mathrm{c} 2$ cells. We then investigated the protective effect of curcumin against $\mathrm{H}_{2} \mathrm{O}_{2}$-induced cell toxicity by MTT assay. The results showed that curcumin protected $\mathrm{H} 9 \mathrm{c} 2$ cells from $\mathrm{H}_{2} \mathrm{O}_{2}$-induced cytotoxicity in a dose-dependent manner.

We have shown that $\mathrm{H} 9 \mathrm{c} 2$ cells incubation with $400 \mu \mathrm{M}$ of $\mathrm{H}_{2} \mathrm{O}_{2}$ decreased the cell viability about $40 \%$ in comparison to the control. Moreover, typical features of apoptosis such as an increase of phosphatidylserines externalization, an elevated CC3 expression [24] and a decreased $\mathrm{Bcl}-2 / \mathrm{Bax}$ ratio [25] indicate that the cell death observed in the cell viability assay is mainly of apoptotic nature. Recently, curcumin was shown to be implicated in the suppression of apoptosis in various cell types such as vascular smooth muscle cells [26] and renal proximal tubular cells [27]. Our study demonstrated for the first time that $\mathrm{H}_{2} \mathrm{O}_{2}$-induced apoptosis of $\mathrm{H} 9 \mathrm{c} 2$ cells was significantly inhibited by curcumin pretreatment.

Pharmacological and genetic induction of HO-1 has been shown to exert an anti-apoptotic effect in various cardiovascular diseases [28, 29]. A previous study demonstrated that HO-1 was upregulated in endothelial cells [30] and skin fibroblast cells [31] by curcumin in vitro, and here we showed that curcumin induced HO-1 protein expression in a dose-dependent manner in $\mathrm{H} 9 \mathrm{c} 2$ cells. In addition, the anti-apoptotic effect of curcumin was demonstrated to be partly attributed to the induction of HO-1 because the inhibitor of HO-1 (ZnPPIX) markedly reversed the protection of curcumin, as revealed by a decrease of $\mathrm{Bcl}-2 / \mathrm{Bax}$ ratio, and an increase of $\mathrm{CC} 3$ protein expression and apoptotic cells. These results suggest that the induction of HO-1 may play a significant role in mediating the anti-apoptotic effect of curcumin in $\mathrm{H}_{2} \mathrm{O}_{2}$-stimulated $\mathrm{H} 9 \mathrm{c} 2$ cells.

Since PI3K/Akt and ERK1/2 are the common signaling pathways for the modulation of HO-1 expression [17, 18], the influence of curcumin on the phosphorylation of Akt and ERK1/2 was measured. In our study, curcumin activated the PI3K/Akt pathway, but not the ERK1/2 pathway. These effects of curcumin are consistent with previous evidence using rat aortic vascular smooth muscle cells [26]. This means that it is the phosphorylation of Akt but not ERK1/2 involved in curcumin-mediated protection. Although most studies showed the PI3K/Akt pathway participated in the regulation of HO-1 expression, the role of Akt phosphorylation in $\mathrm{HO}-1$ activation 


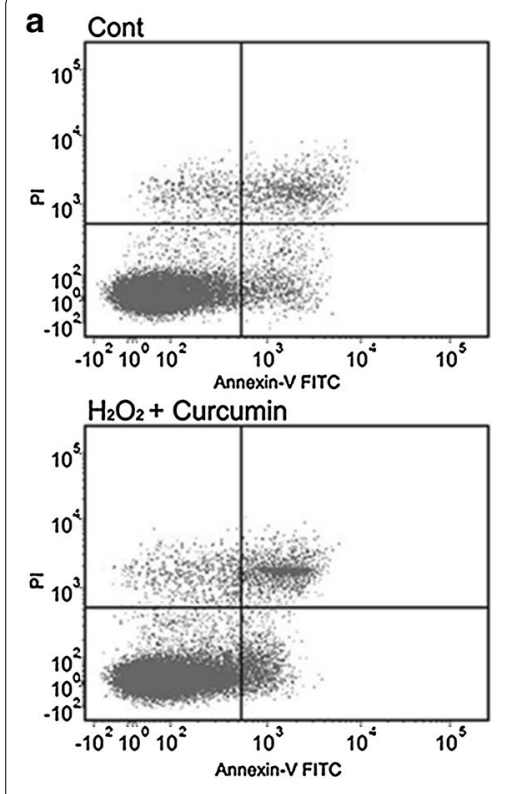

C

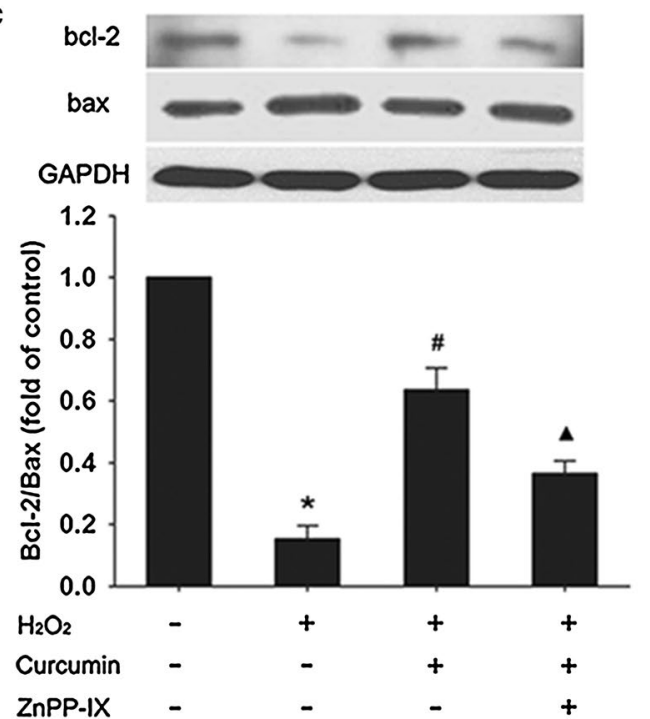

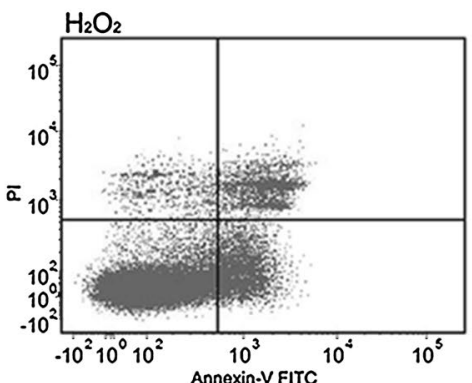

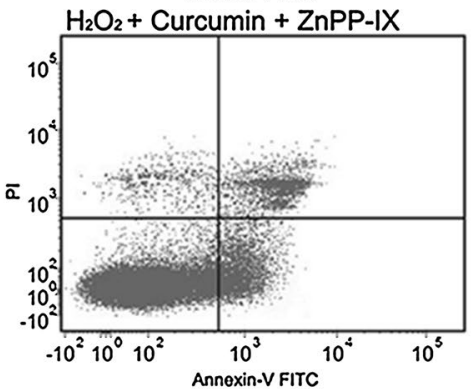

b

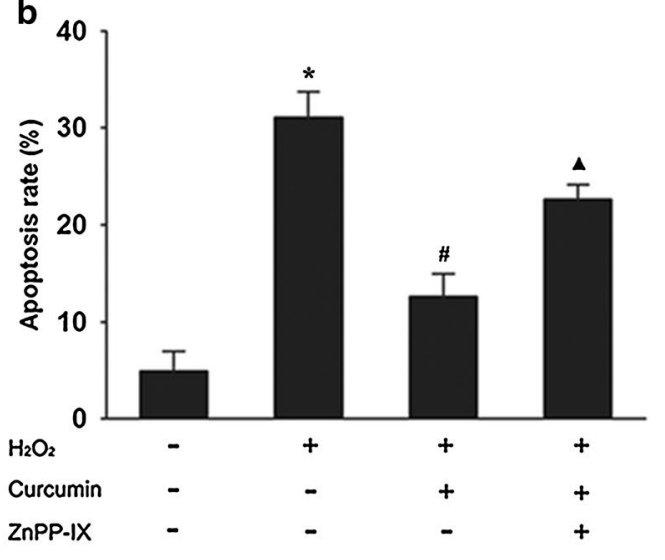

d

d $\mathrm{cc3}$
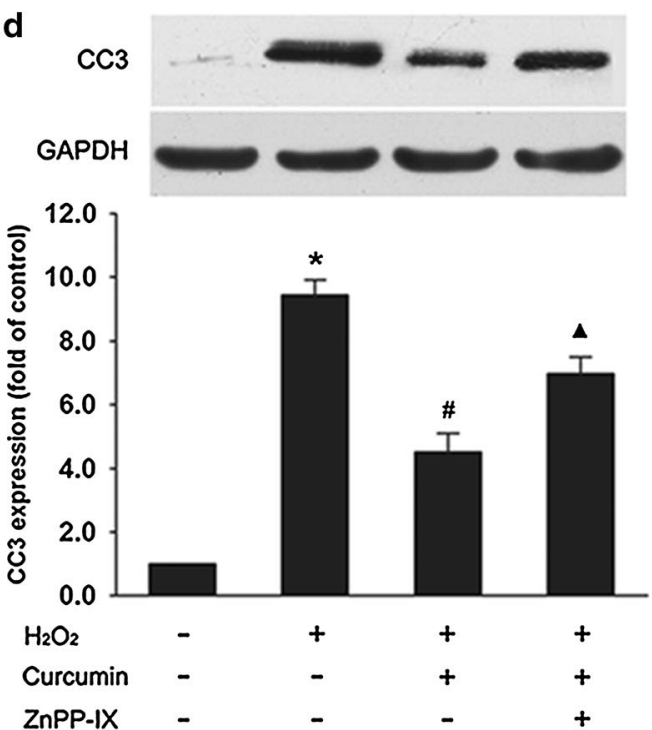

Fig. 3 The anti-apoptotic effect of curcumin was partly reversed by ZnPP-IX. After pretreated with $15 \mu \mathrm{M}$ of curcumin for $12 \mathrm{~h}$ in the absence or presence of $10 \mu \mathrm{M} Z \mathrm{ZnPP}-\mathrm{IX}$, the cells were washed and incubated with $400 \mu \mathrm{M} \mathrm{H}_{2} \mathrm{O}_{2}$ for $3 \mathrm{~h}$. $\mathbf{a}$, b Percentage of apoptotic cells was detected by flow cytometry analysis using Annexin-V FITC/PI staining. Apoptotic cells included Annexin V (+)/PI $(-)$ and Annexin V $(+) / P I(+)$ cells. c, d The Bcl-2, Bax, and CC3 protein expression were determined by western blot analysis. The Bcl-2/Bax ratio was calculated. Data were presented as mean \pm SD $(\mathrm{n}=3) .{ }^{*} p<0.05$ vs. control, ${ }^{\#} p<0.05$ vs. $\mathrm{H}_{2} \mathrm{O}_{2}, \boldsymbol{\Delta}_{p}<0.05$ vs. $\mathrm{H}_{2} \mathrm{O}_{2}+$ curcumin

still remained controversial. For instance, in agreement with our data, pharmacological activation of the PI3K/ Akt pathway by carnosol (a constituent of the herb of rosemary), which led to the induction of HO-1 protein, efficiently protected rat pheochromocytoma PC12 cells against oxidative stress [32]. However, piceatannol which is an anti-inflammatory and anti-proliferative plantderived stilbene elevated HO-1 protein levels in bovine aortic endothelial cells via PKC and tyrosine kinase pathways, but not the PI3K/Akt pathway [33]. A possible explanation for these different findings could be that the mechanisms of HO-1 activation induced by various chemicals may differ significantly in different cell types. Our results are consistent with the requirement of Akt phosphorylation for the upregulation of $\mathrm{HO}-1$ by curcumin because upregulation of $\mathrm{HO}-1$ expression induced by curcumin was partly blocked by LY294002. In addition, LY294002 also partially reversed the anti-apoptotic 


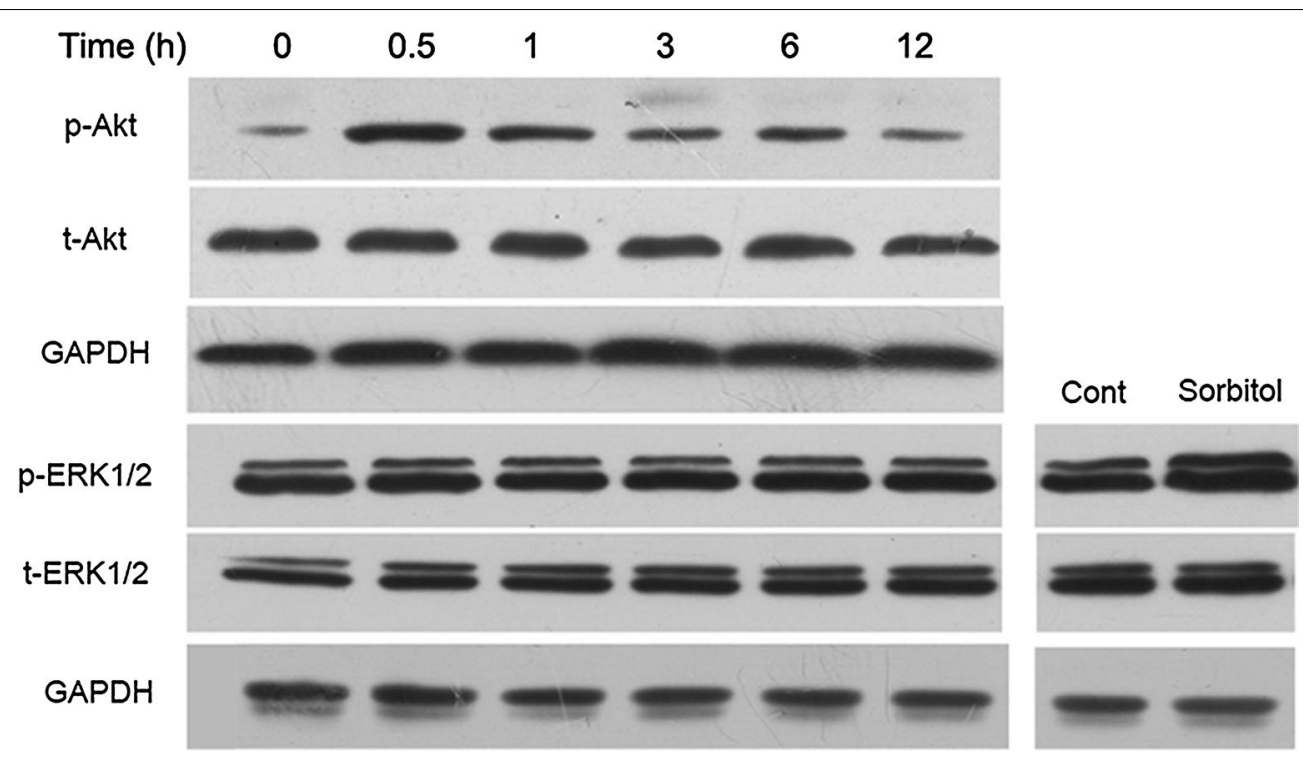

Fig. 4 Curcumin enhanced phosphorylation of Akt but had no influence on ERK1/2 phosphorylation. Cells were treated with $15 \mu \mathrm{M}$ curcumin for the indicated times. The expression levels of p-Akt, t-Akt, p-ERK1/2 and t-ERK1/2 were measured by western blot analysis. Cell extracts from H9c2 cells stimulated by osmotic shock $(0.5 \mathrm{M}$ sorbitol, $30 \mathrm{~min}$ ) served as a positive control. Representative blots of three independent experiments were shown

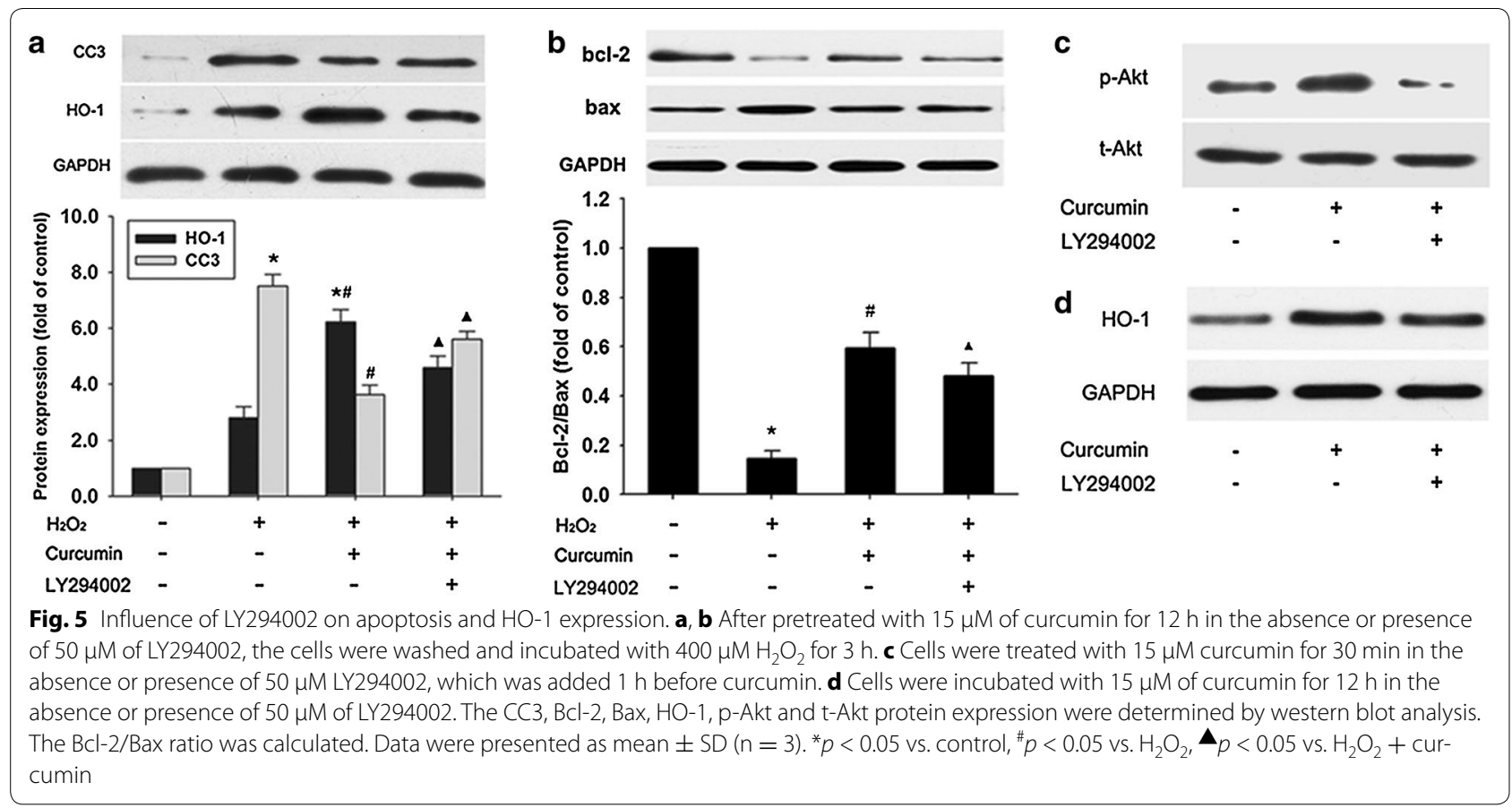

effect of curcumin. These results suggested that the induction of HO-1 through the PI3K/Akt pathway was critically involved in curcumin-mediated apoptosis resistance.

ZnPP-IX, significantly, but not completely, suppressed the anti-apoptotic effect of curcumin against $\mathrm{H}_{2} \mathrm{O}_{2}$. This data suggested that the anti-apoptotic effect of curcumin was probably attributed not only to the involvement of $\mathrm{HO}-1$ but also to other elements. In addition, inhibition of PI3K/Akt pathway did not entirely reverse the curcumin-induced increase in HO-1 protein levels, suggesting that other PI3K/Akt-independent pathways are also 
involved in the effect of curcumin on HO-1. Moreover, a previous study showed that $\mathrm{CO}$ and bilirubin, products of heme metabolism by HO-1, exhibited a potent antiapoptotic effect in doxorubicin-stimulated H9c2 cells [34], however, whether $\mathrm{CO}$ or bilirubin is involved in the cytoprotection afforded by curcumin is still unknown. Thus, experiments aimed at broadening our understanding of the more detailed mechanisms will be the subject of interest in future studies.

\section{Conclusions}

Our results demonstrated that curcumin can protect $\mathrm{H} 9 \mathrm{c} 2$ cells from $\mathrm{H}_{2} \mathrm{O}_{2}$-induced apoptosis and that such anti-apoptotic effect largely depends on the upregulation of HO-1 protein expression through the PI3K/Akt pathway. As a consequence, we speculate that curcumin, which exerts potential protection against oxidative stress-mediated apoptosis, might be used as a preventive and therapeutic agent for treatment of cardiovascular diseases associated with oxidative stress.

\section{Abbreviations \\ $\mathrm{H}_{2} \mathrm{O}_{2}$ : hydrogen peroxide; $\mathrm{HO}-1$ : heme oxygenase-1; CC3: cleaved caspase-3; ROS: reactive oxygen species; $\mathrm{CO}$ : carbon monoxide; PKB: protein kinase $\mathrm{B}$; PI3 K: phosphoinositide 3-kinase; ERKs: extracellular signal-regulated kinases; MTT: methyl thiazolyl tetrazolium; ZnPP-IX: Zine protoporphyrin-IX; DMSO: dimethyl sulfoxide; ATCC: American Type Culture Collection.}

\section{Authors' contributions}

YS drafted the manuscript. XY participated in the design of the study and performed the statistical analysis. HJ conceived of the study, and participated in its design and coordination and helped to draft the manuscript. All authors read and approved the final manuscript.

\section{Author details}

${ }^{1}$ Department of Ophthalmology, Union Hospital, Tongji Medical College, Huazhong University of Science and Technology, Wuhan 430022, China.

${ }^{2}$ Department of Neonatology, The Central Hospital of Wuhan, Tongji Medical College, Huazhong University of Science and Technology, Wuhan, 430014, China.

\section{Acknowledgements}

Not applicable.

\section{Competing interests}

The authors declare that they have no competing interests.

\section{Availability of data and materials}

The datasets used and/or analyzed during the current study available from the corresponding author on reasonable request.

\section{Funding}

This research is supported in part by the National Science Foundation of China (No. 30973228).

\section{Publisher's Note}

Springer Nature remains neutral with regard to jurisdictional claims in published maps and institutional affiliations.

Received: 5 January 2017 Accepted: 19 April 2017

Published online: 21 April 2017
References

1. Abbate A, Bussani R, Amin MS, Vetrovec GW, Baldi A. Acute myocardial infarction and heart failure: role of apoptosis. Int J Biochem Cell Biol. 2006;38:1834-40.

2. Buja LM. Myocardial ischemia and reperfusion injury. Cardiovasc Pathol. 2005; 14:170-5.

3. Halliwell B, Aruoma OI. DNA damage by oxygen-derived species Its mechanism and measurement in mammalian systems. FEBS Lett. 1991;281:9-19.

4. Hensley K, Robinson KA, Gabbita SP, Salsman S, Floyd RA. Reactive oxygen species, cell signaling, and cell injury. Free Radic Biol Med. 2000;28:1456-62

5. Ammon HP, Wahl MA. Pharmacology of Curcuma longa. Planta Med. 1991;57:1-7.

6. Shishodia S, Sethi G, Aggarwal BB. Curcumin: getting back to the roots. Ann NY Acad Sci. 2005;1056:206-17.

7. Scharstuhl A, Mutsaers HA, Pennings SW, Szarek WA, Russel FG, Wagener FA. Curcumin-induced fibroblast apoptosis and in vitro wound contraction are regulated by antioxidants and heme oxygenase: implications for scar formation. J Cell Mol Med. 2009;13:712-25.

8. Liu W, Fan Z, Han Y, Lu S, Zhang D, Bai X, Xu W, Li J, Wang H. Curcumin attenuates peroxynitrite-induced neurotoxicity in spiral ganglion neurons. Neurotoxicology. 2011;32:150-7.

9. Mito S, Thandavarayan RA, Ma M, Lakshmanan A, Suzuki K, Kodama M, Watanabe K. Inhibition of cardiac oxidative and endoplasmic reticulum stress-mediated apoptosis by curcumin treatment contributes to protection against acute myocarditis. Free Radic Res. 2011;45:1223-31.

10. Bae JW, Kim MJ, Jang CG, Lee SY. Protective effects of heme oxygenase-1 against MPP(+)-induced cytotoxicity in PC-12 cells. Neurol Sci. 2010:31:307-13.

11. Bao W, Li K, Rong S, Yao P, Hao L, Ying C, Zhang X, Nussler A, Liu L. Curcumin alleviates ethanol-induced hepatocytes oxidative damage involving heme oxygenase-1 induction. J Ethnopharmacol. 2010;128:549-53.

12. Katori M, Buelow R, Ke B, Ma J, Coito AJ, Iyer S, Southard D, Busuttil RW, Kupiec-Weglinski JW. Heme oxygenase-1 overexpression protects rat hearts from cold ischemia/reperfusion injury via an antiapoptotic pathway. Transplantation. 2002;73:287-92.

13. Xu JJ, Wang YL. Propofol attenuation of hydrogen peroxide-mediated oxidative stress and apoptosis in cultured cardiomyocytes involves haeme oxygenase-1. Eur J Anaesthesiol. 2008;25:395-402.

14. Zheng Y, Liu Y, Ge J, Wang X, Liu L, Bu Z, Liu P. Resveratrol protects human lens epithelial cells against $\mathrm{H}_{2} \mathrm{O}_{2}$-induced oxidative stress by increasing catalase, SOD-1, and HO-1 expression. Mol Vis. 2010;16:1467-74.

15. Franke TF, Hornik CP, Segev L, Shostak GA, Sugimoto C. PI3K/Akt and apoptosis: size matters. Oncogene. 2003;22:8983-98.

16. Zhuang S, Schnellmann RG. A death-promoting role for extracellular signal-regulated kinase. J Pharmacol Exp Ther. 2006;319:991-7.

17. Hsu CL, Wu YL, Tang GJ, Lee TS, Kou YR. Ginkgo biloba extract confers protection from cigarette smoke extract-induced apoptosis in human lung endothelial cells: role of heme oxygenase-1. Pulm Pharmacol Ther. 2009;22:286-96.

18. Kim JW, Li MH, Jang JH, Na HK, Song NY, Lee C, Johnson JA, Surh YJ. 15-Deoxy-Delta(12,14)-prostaglandin J(2) rescues PC12 cells from $\mathrm{H}_{2} \mathrm{O}_{2}$-induced apoptosis through $\mathrm{Nrf2}$-mediated upregulation of heme oxygenase-1: potential roles of Akt and ERK1/2. Biochem Pharmacol. 2008;76:1577-89.

19. Turner NA, Xia F, Azhar G, Zhang X, Liu L, Wei JY. Oxidative stress induces DNA fragmentation and caspase activation via the c-Jun $\mathrm{NH}_{2}$-terminal kinase pathway in $\mathrm{H} 9 \mathrm{c} 2$ cardiac muscle cells. J Mol Cell Cardiol. 1998;30:1789-801.

20. Gardner AM, Xu FH, Fady C, Jacoby FJ, Duffey DC, Tu Y, Lichtenstein A. Apoptotic vs. nonapoptotic cytotoxicity induced by hydrogen peroxide. Free Radic Biol Med. 1997;22:73-83.

21. Wang B, Shravah J, Luo H, Raedschelders K, Chen DD, Ansley DM. Propofol protects against hydrogen peroxide-induced injury in cardiac $\mathrm{H} 9 \mathrm{c} 2$ cells via Akt activation and Bcl-2 up-regulation. Biochem Biophys Res Commun. 2009;389:105-11.

22. Yu W, Fu YC, Zhou XH, Chen CJ, Wang X, Lin RB, Wang W. Effects of resveratrol on $\mathrm{H}_{2} \mathrm{O}_{2}$-induced apoptosis and expression of SIRTs in H9c2 cells. J Cell Biochem. 2009;107:741-7. 
23. Mattson MP, Cheng A. Neurohormetic phytochemicals: low-dose toxins that induce adaptive neuronal stress responses. Trends Neurosci. 2006:29:632-9.

24. Zhang $X$, Zhao M, Chen L, Jiao H, Liu H, Wang L, Ma S. A triterpenoid from Thalictrum fortunei induces apoptosis in BEL-7402 cells through the P53induced apoptosis pathway. Molecules. 2011;16:9505-19.

25. Kim IS, Choi DK, Jung HJ. Neuroprotective effects of vanillyl alcohol in Gastrodia elata Blume through suppression of oxidative stress and antiapoptotic activity in toxin-induced dopaminergic MN9D cells. Molecules. 2011;16:5349-61.

26. Kang ES, Woo IS, Kim HJ, Eun SY, Paek KS, Chang KC, Lee JH, Lee HT, Kim $\mathrm{JH}$, Nishinaka T, Yabe-Nishimura C, Seo HG. Up-regulation of aldose reductase expression mediated by phosphatidylinositol 3-kinase/Akt and $\mathrm{Nrf2}$ is involved in the protective effect of curcumin against oxidative damage. Free Radic Biol Med. 2007;43:535-45.

27. Bhaskaran M, Reddy K, Radhakrishanan N, Franki N, Ding G, Singhal PC. Angiotensin II induces apoptosis in renal proximal tubular cells. Am J Physiol Renal Physiol. 2003;284:F955-65.

28. Wang G, Hamid T, Keith RJ, Zhou G, Partridge CR, Xiang X, Kingery JR, Lewis RK, Li Q, Rokosh DG, Ford R, Spinale FG, Riggs DW, Srivastava S, Bhatnagar A, Bolli R, Prabhu SD. Cardioprotective and antiapoptotic effects of heme oxygenase- 1 in the failing heart. Circulation. 2010;121:1912-25.
29. Yeh CH, Chen TP, Wang YC, Lin YM, Lin PJ. HO-1 activation can attenuate cardiomyocytic apoptosis via inhibition of NF-kappaB and AP-1 translocation following cardiac global ischemia and reperfusion. J Surg Res. 2009; 155:147-56

30. Motterlini R, Foresti R, Bassi R, Green CJ. Curcumin, an antioxidant and anti-inflammatory agent, induces heme oxygenase-1 and protects endothelial cells against oxidative stress. Free Radic Biol Med. 2000;28:1303-12.

31. Lima CF, Pereira-Wilson C, Rattan SI. Curcumin induces heme oxygenase-1 in normal human skin fibroblasts through redox signaling: relevance for anti-aging intervention. Mol Nutr Food Res. 2011:55:430-42.

32. Martin D, Rojo Al, Salinas M, Diaz R, Gallardo G, Alam J, De Galarreta CM, Cuadrado A. Regulation of heme oxygenase-1 expression through the phosphatidylinositol 3-kinase/Akt pathway and the Nrf2 transcription factor in response to the antioxidant phytochemical carnosol. J Biol Chem. 2004:279:8919-29.

33. Wung BS, Hsu MC, Wu CC, Hsieh CW. Piceatannol upregulates endothelia heme oxygenase-1 expression via novel protein kinase $C$ and tyrosine kinase pathways. Pharmacol Res. 2006;53:113-22.

34. Kim DS, Chae SW, Kim HR, Chae HJ. CO and bilirubin inhibit doxorubicin-induced cardiac cell death. Immunopharmacol Immunotoxicol. 2009;31:64-70

\section{Submit your next manuscript to BioMed Central and we will help you at every step:}

- We accept pre-submission inquiries

- Our selector tool helps you to find the most relevant journal

- We provide round the clock customer support

- Convenient online submission

- Thorough peer review

- Inclusion in PubMed and all major indexing services

- Maximum visibility for your research

Submit your manuscript at www.biomedcentral.com/submit 